\title{
Empowering Residents of The Former Dolly's Prostitution Localization as an Effort of Government Economic Responsibility of Surabaya City
}

\author{
${ }^{1}$ Siska Armawati Sufa, ${ }^{2}$ Atalia Praratya, ${ }^{3}$ Suwandi Sumartias, ${ }^{4}$ Jamilah Ahmad \\ \{siska19003@mail.unpad.ac.id $\left.{ }^{1}\right\}$ \\ 1,2,3Padjajaran University, Bandung, Indonesia \\ ${ }^{4}$ Universiti Sains Malaysia, Penang, Malaysia
}

\begin{abstract}
The existence of Dolly's localization as the largest prostitution center in Southeast Asia located in Surabaya is not a proud achievement for the Surabaya city government, when Tri Rismaharini as the mayor officially closed it on June 8th, 2014, residents around the former Dolly localization lost many of their livelihoods and declining incomes. The city government of Surabaya for five years has been trying to reform to change the image of the former Dolly localization as one of the centers of micro, small, and medium enterprises (MSMEs) in addition to run the government's economic responsibility program. This research uses a systemic approach which is one alternative to see the relationship between government and its citizens, trying to find out how the Surabaya city government changed the economic system in the former Dolly localization to a populist-based economic activity by empowering the economic activities of citizens in the former Dolly localization despite the practice prostitution has been closed, and uses qualitative methods through interview techniques to the Public Relations Division of the Surabaya City Government, and public relations agencies or private companies (key informants) and citizens in the former Dolly localization area (informant). Based on the results of the study it was concluded that the Surabaya city government has collaborated with various private agencies in implementing an empowerment program for the community of the former Dolly localization as compensation for the closure of prostitution in the area.
\end{abstract}

Keywords: Dolly, Surabaya, Government, Economic, Responsibilities, Empowering

\section{Introduction}

A more complex assumption or concept about government today is the government as a provider, in this case, the government acts as a provider of goods and services that individuals cannot provide for them. The government in this conception is a solution to the problem of collective action, where citizens create public goods that benefit everyone.

Slaughter [1] the basic economic infrastructure of human connectivity falls into this category: physical travel facilities, such as highways, bridges and various types of ports, and increasingly virtual travel facilities, such as broadband. All of this infrastructure exists, and usually initially, is provided by private entrepreneurs who see the opportunity to build roads, assign and charge fees to users, but the capital required is very large and the public benefits are very clear so that ultimately the government takes over.

The broader concept of government is as a state institution that embodies social welfare for its people, in the sense that the government can support the inability of citizens to meet their own needs, especially in vulnerable conditions that are usually experienced by 
young people, the elderly, sick, disabled and unemployed because of the existence of economic forces outside the control of society. If the government as a state institution can evolve to realize social welfare for its people, this is considered as an effort to protect society from capitalism. However, the best effort is to provide all forms of infrastructure to enable citizens to grow socially and economically so that they can face competition, and provide social security that enables citizens to create economic security for themselves.

The future of the government is built on the fundamentals of protecting and providing infrastructure for the economic life of the people. The government is obliged to seek protection for citizens from violence and the decline in the quality of life. The government will continue to provide public infrastructure, at a level that is adjusted to the needs of each people to ensure an increase in a globally competitive economy and an increase in people's welfare. On the other hand, the government must also invest in developing the capabilities of the people so that they are capable to provide for their needs and improve their well-being in a fast-paced and changing environment at all times, one of them is in economics.

The government's involvement in the economy, in the narrowest sense, is to help fix market failures and conditions where private markets cannot maximize the value they can produce for society. This covers the provision of public goods, the internalization of externalities (economic impact on unidentified third parties) and market control [2].

Empowerment can be interpreted as a delegation power that produces a hierarchy of power and a lack of power [3]. Empowerment involves two patterns, the first is the empowerment process, which emphasizes the process of giving or passing any energy, power or resources to the community in order to empower individuals, while the second is that empowerment actors are not only needed to enhance their awareness but are also required to increase their skills in the development of empowerment programs [4].

Empowering the community is an attempt to improve the integrity and status of the lower layers of society (grass-root), which with all its shortcomings have not been able to escape the pitfalls of deprivation, ignorance, and underdevelopment so that empowerment of the community not only enhances individuals but also existing social institutions. It is an important part of empowerment strategies to instill traditional culture ideals such as hard work, frugality, honesty, accountability. Community empowerment is the theory of economic developl7hnnment which encapsulates the community's principles to create a new paradigm of people-centered, participatory [5].

Good cooperation between the government and the community in the empowerment efforts carried out can increase economic independence, especially in the productivity and income of people who get help [6] one of them is a resident around the former Dolly localization.

The history of Dolly localization or Gang Dolly is the name of a prostitution area in Putat Jaya, Sawahan, Surabaya City, East Java, Indonesia scattered in 5 location points. In this area of the venue, comfort women are "visible" in a display case in a glass-walled room. Until now [7], the prostitution localization Dolly born and grow with the growth of the city of Surabaya. In particular, some Surabaya residents depend on the long-established economic system with the localization of Dolly's prostitution. As a localization practice of prostitution, Dolly has become the biggest trendsetter in the Southeast Asian region. The appearance, quality of services, and physical of sex-workers make migrants or women victims of urbanization come to Dolly when they do not have a bargaining position to get more decent work with demands for qualified skills and competencies.

Although the Surabaya city government has officially closed the former Dolly localization, there are still people who are determined to open up the practice of prostitution in a veiled 
manner. The Surabaya city government [8] has had to worry about the fate of thousands of sex maids at Dolly's location since closing activity about prostitution practice in the Dolly area. Because there are too many people in the Dolly area drape its economic to the prostitution activity in there, from jobs as parking attendants to jobs that are considered immoral, including prostitutes and pimps. So the closure of Dolly prostitution localization has suddenly stopped the economic system that has formed in the Dolly area, which has been rolling every day.

The Mayor of Surabaya, Tri Rismaharini has stated that all prostitution localizations located throughout the Surabaya city, including in the Dolly area located in Putat Jaya, violated Regional Regulation No. 7 of 1999 concerning a ban on the use of buildings as immoral sites. In this case, Risma wants to emphasize to all citizens to try to make a more decent living without having to open immoral business practices. The effort made by Risma is to provide motivation and empower residents who are in the former prostitution localization by providing new business opportunities tailored to their respective expertise. Risma seeks to focus on the integrity of women to be more efficient and have income from the creative economic system. The closure of prostitution localization more deeply seeks to overcome various problems related to the moral education of children and adolescents around the Dolly localization, because the existence of prostitution localization has a psychological impact, especially for children who live in the area [9].

From this problem, this research tries to find out how the Surabaya city government empowers residents in the former Dolly localization and how the Surabaya city government changes the economic system in the former Dolly localization to become a community-based economic activity even though the practice of prostitution has been closed, using a systemic approach which is one of alternative to analyze the relationship between the government and its citizens in advancing the economy of Surabaya.

\section{Research Method}

This research is a study that uses a qualitative approach with the interview method. Qualitative research [10] focuses primarily on the use of tools to analyze and understand the meaning in which certain individuals or groups are perceived to have resulted from a social or human problem. The interview [11] is a method of gathering research data independently and systematically by one-way questions and answers and providing a framework for research goals.

In this study, researchers will explore information through interviews with Government Public Relations of the Surabaya City to find out what efforts the Surabaya City Government has made in empowering the community in the former Dolly localization.

\section{Result}

The Surabaya city government has collaborated with various stakeholders (institutions, agencies, and or private companies) in implementing an empowerment program for the community of the former Dolly localization as compensation for the closure of prostitution in the area. Some of them are Airlangga University Surabaya, November 10 Institute of Technology Surabaya, and almost all universities in Surabaya. As well as several hotels in Surabaya, approximately 60 hotels have participated in developing Micro and Small and 
Medium Enterprises (MSMEs) in the former Dolly localization area. Also, cooperation was established with PT. Astra International, Tbk. through The Social Agency of Surabaya City Government to assist Children with Special Needs who live in the area.

Various efforts have been and continue to be made by the Surabaya city government as a manifestation of the Government's Economic Responsibility so that people who live in the former localization of Dolly can continue their economic activities and apart from the practice of prostitution which so far has been an established economic system and has a wide impact on the people of Surabaya.

There are many programs that are the result of collaboration between the Surabaya city government and several stakeholders, some of the empowerment programs that were being carried out when this research was reported, including 1) Dolly English Club, which was initiated by Dr. Soetomo University Surabaya, and 2) Batik Houses fostered by Petra Christian University Surabaya.

Residents of the former Dolly localization are currently receiving free English training courses. The area that was once known as a prostitution area now changes to being a place for residents in Dolly to learn English in informal class. The English language training program for all residents in the former Dolly localization area is an effort to add insight and ability in foreign languages so that they can actualize like other Surabaya residents normally because not all people can accept the present residents of the former Dolly localization.
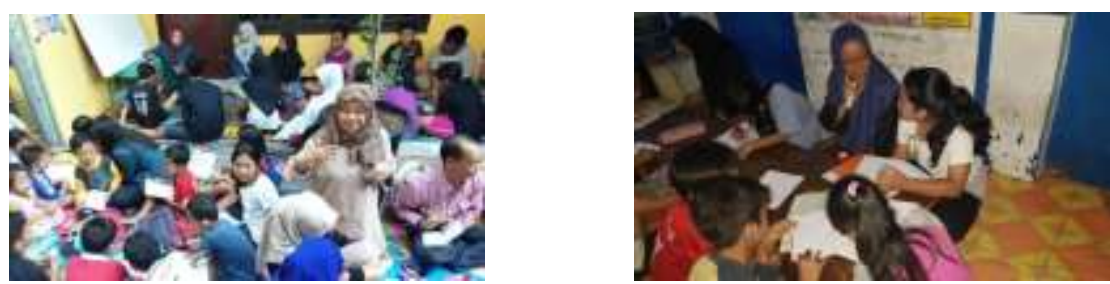

Figure 1. Dr. Soetomo University Surabaya provides English language training with the residents in the former Dolly localization

All residents from family, daughters, and mothers, middle school teens, and kindergarten children to elementary schools totalling nearly 800 residents from all Dolly area attended the Dolly English Club event, which took every Sunday in meeting room of Putat Jaya Timur. The mastery aspects of foreign languages, especially English for residents of the former Dolly localization are considered very useful in improving personality and confidence, because through language every man can convey the intentions of desires as social beings to meet their needs. The English program for residents in the former Dolly localization as an implementation of the Government Economic Responsibility of Surabaya city government in the form of providing learning facilities for residents of the former Dolly localization to improve their quality so that they can compete with other citizens.

Another empowerment program for residents of the former Dolly localization is also run by the Surabaya city government in collaboration with Petra Christian University Surabaya through entrepreneurship coaching at the Rumah Batik Dolly (Dolly Batik House). This training is given to develop knowledge and skills of business innovation strategies in producing Surabaya's Batik. The main objective of this empowerment program is to create a new economic system in the field of Micro, Small and Medium Enterprises that will specifically improve the economic system of Dolly residents.

This training activity emphasizes aspects of developing creativity in the process of batik designs. By trying to use Batik cloth, it is processed into various variants of economically 
valuable products. Petra Christian University lecturers have held creativepreneur training program for residents of the former Dolly localization since April 2019 once a week. The training included 5 representatives of batik artisans and 5 others were housewives who wanted to learn more details about the production of batik crafts. This training produced 10 variants of batik motifs including butterfly, guava leaf, castor leaf, and kale vegetables.
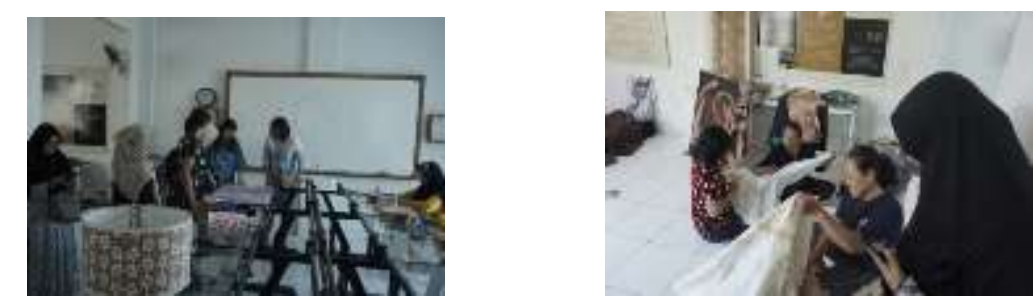

Figure 2. Residents of Kampung Dolly are making batik as well as being fostered by lecturers from Petra Christian University Surabaya in creating the latest batik motifs

In addition to the empowerment efforts undertaken by the Surabaya city government in cooperation with several universities in East Java, the Surabaya city government has at least succeeded in creating new business opportunities for residents living in the former Dolly localization. The efforts of the Surabaya city government to collaborate with various stakeholders to make Kampung Dolly as one of the Micro, Small and Medium Enterprises Centers in Surabaya have produced many products in the form of Batik, consisting of four MSME partner groups, namely Jarak Arum, Alpujabar, Canting Surya, and Warna Ayu. Meanwhile, for food and beverage products there are 13 groups of MSME partners with, namely TBM Kawain, Olahan Bandeng, Jarwo Tempe, Sami Jali, Pangsit Hijau, Cak Mimin (Dian Rujak), UKM Puja (salted egg, and or dish made of coconut and salted egg wrapped in banana leaf and steamed), UKM Squel (all kind of chips), UKM Vigts (herbal medicine), Gendis (Pecel seasoning or spicy peanut seasoning), UKM Henrik (processed clover and ice puter) and processed drinks from seaweed.

The government public relations of Surabaya city conducted research before running the empowerment program as a management public relations step, adjusted to the needs and capabilities of citizens who lived in the former Dolly localization. The program was carried out from upstream to downstream according to the open organization system. Thinking about starting from the appropriate business opportunity, product innovation strategy to promotion and sales of products, including efforts to socialize the program so that it can be well received by the citizens. The empowerment program, which was initially firmly rejected by residents of Kampung Dolly, has increasingly shown positive results. Many foreign tourists have visited MSME Centers in that former prostitution localization Dolly, such as foreign tourists from Brunei Darussalam, Korea, Malaysia, Singapore. Even today, demand to supply products various hotel amenities such as hotel slippers and so forth more increase.

The study of organizations as an open approach, in principle, is to study the process of organizational adaptation to its environment. This adaptation process is carried out starting from upstream (backward linkages) to downstream (foreward likages), which starts from the input environment in an effort to obtain the necessary resources (resourcess), to the output environment to offer all kinds of products it produces. Thus, for an organization, that adaptation activities to its environment is a necessity, namely by taking strategic actions so that the organization can conduct a reciprocal transaction that is mutually beneficial to its environment [12]. 
Essentially empowerment is creating atmosphere or climate which allows the potential of the community to develop (enabling). This logic is based on the assumption that it does not exist a society that has absolutely no power. Every society certainly have power, but sometimes they don't realize or that power is still not explicitly known. Therefore the power must be extracted and then developed. If this assumption develops so empowerment is an effort to building power, by encouraging, motivating and raise awareness of the potential possessed and strive to develop it. In addition, empowerment should don't trap the community in the trap of dependency (charity), empowerment on the contrary must lead to the process independence [13]. Empowerment carried out by the Surabaya city government seeks to make residents of the former Dolly localization being independent through the provision of facilities and coaching to open new business opportunities so that they have competitiveness but are adjusted to their needs and abilities.

\section{CONCLUSION}

The Surabaya city government has succeeded in empowering affected citizens to close the localization of Dolly prostitution by changing the immoral economic system and violating the laws and regulations through cooperation with various stakeholders (universities, and private companies) through the provision of facilities in the form of new business opportunities so community members in the former Dolly localization to be more innovative, competitive and self-reliant in the economic field.

\section{ACKNOWLEDGMENT}

A project of this magnitude requires a network of support. I am particularly grateful to proudly mayor, Tri Rismaharini and Muhammad Vikser as a Government PR of Surabaya, East Java, Indonesia for making the study possible, to Atalia Praratya as my partner in this research, and Jamilah Ahmad as candidate co-promotor of my Ph.D program. I will continue to develop research on government economic responsibilities, especially about the Government Public Relations.

\section{REFERENCES}

[1] A. Marie Slaughter, 3 Responsibilities Every Government has Towards its Citizens. America: World Economic Forum of New America. America: World Economic Forum of New America, 2017, cited from: https://www.weforum.org/agenda/2017/02/governmentresponsibility-to-citizens-anne-marie-slaughter/, on June $27^{\text {th }}, 2018$.

[2] Moffatt, Mike. The Government's Role in the Economy. cited from: https://www.thoughtco.com/the-governments-role-in-the-economy-1147544. 2019.

[3] H. Simon, Hutan Jati dan Kemakmuran, Problematika dan Strategi Pemecahannya, Yogyakarta: Aditya Media, 1993

[4] Pramarka \& Vidhyandika, Pemberdayaan: Konsep, Kebijakan, dan Implementasi, Jakarta: Center for Strategic and International Studies (CSIS), 1996

[5] Noor. M., Pemberdayaan masyarakat, CIVIS, l(2/Juli), 2011.

[6] Kurniawati. D., Pemberdayaan masyarakat di bidang usaha ekonomi (studi pada Badan Pemberdayaan Masyarakat kota Mojokerto),Jurnal Administrasi Publik, 1(4), 9-14), 2013. 
[7] Wicaksono. G. A., Deligitimasi Kebijakan Penataan Ulang Wisata Prostitusi Dolly: Studi Deskriptif Perlawanan Komunitas Dolly (Doctoral dissertation, Universitas Airlangga), 2012.

[8] Wijaya. B., Dolly Ditutup, Muncul Masalah Baru bagi Pemkot Surabaya, Cited from; https://www.kompasiana.com/bayuyanuar/54f6f4cca333114b088b45da/dolly-ditutupmuncul-masalah-baru-bagi-pemkot-surabaya, 2014.

[9] Andriansyah. M., Ini alasan Risma mati-matian tutup lokalisasi Gang Dolly, cited from: https://www.merdeka.com/peristiwa/ini-alasan-risma-tutup-lokalisasi-gang-dolly-matimatian.html, 2014.

[10] Creswell. J, Qualitative Inquiry and Research Design: Choosing among Five Approaches, $2,2010$.

[11] Sutrisno. Hadi, Analisis Regresi, Yogyakarta: Andi Offset, 2004.

[12] J. Woodward, Industrial Organization: Theory and Practice, London: Oxford University Press, 1965.

[13]T. Winari. Memahami Pemberdayaan Masyarakat Desa Partisipatif dalam Orientasi Pembangunan Masyarakat Desa Menyongsong Abad 21: Menuju Pemberdayaan Pelayanan Masyarakat, Yogyakarta: Aditya Media, 1998. 